\title{
The influence of He-Ne laser on agro- morphological criteria, ISSR marker and SDS-PAGE of Moringa oleifera
}

\author{
Samira A. Osman ${ }^{1 *}$ (D) and Walaa A. Rayan²
}

\begin{abstract}
Background: Moringa oleifera L. (moringa) is a promising plant for nutritionally and medicinally uses. The influence of laser radiation on moringa seeds (dry and wetted) was investigated, using helium-neon ( $\mathrm{He}-\mathrm{Ne}$ ) laser source at $\Lambda=632.8 \mathrm{~nm}$ wavelength and $5 \mathrm{~cm}$ beam diameter for 25, 45, and $90 \mathrm{~min}$. Agro-morphological criteria, SDS-PAGE protein banding patterns, and ISSR markers were investigated to elucidate the influence of He-Ne laser on moringa.

Results: Most agro-morphological criteria increased especially with wetted seed group pre-laser treatments (25 min). SDS-PAGE and ISSR profiles showed changes which include the absence of some bands and the appearance of few novel bands. ISSR markers showed a change in band number in all investigated samples with a total number of 172 bands. The polymorphic bands were 91 bands with 19 unique bands. The average mean percentage of polymorphism was recorded $52.91 \%$ at samples treated with a laser at different times. Wetted seed treatment for 25 min recorded 40 bands as new bands. Genetic template stability (GTS) values were recorded in all treatments. The lowest GTS \% was recorded 76.74 at 25 min (wetted seeds) while highest GTS \% was recorded 83.72 at 25 min (dry seeds). According to the data of GTS, produced by laser treatment for 25 and 45 min for wetted and dry seeds, respectively, it is more effective on genome stability than other treatments.

Conclusion: He-Ne laser treatments of wetted seeds achieve biostimulation in many aspects of agromorphological criteria. ISSR analysis is a highly sensitive method for the detection of DNA alteration induced by laser treatments. The exposure of dry and wetted seeds to He-Ne laser at different times affected the genomic template stability percentage (GTS \%). Also, the laser treatments have a great effect on gene expression by switching on or off some genes that may lead to the presence or absence of certain proteins, respectively.
\end{abstract}

Keywords: He-Ne laser, Agro-morphological criteria, SDS-PAGE, ISSR marker, Genomic template stability (GTS), Moringa oleifera

\section{Introduction}

Genus Moringa belongs to an angiosperm family (Moringaceae); it consists of 13 species such as Moringa oleifera. M. oleifera is widely cultivated over the world for its nutritional and medicinal values (Leone et al. 2015). M. oleifera is used as human food, medicinal plant, animal fodder, fertilizer, antimicrobial substance, bio-fuel, and ornamental plant (Gopalakrishnan et al. 2016).

\footnotetext{
*Correspondence: s_nrc82@yahoo.com

${ }^{1}$ Genetics and Cytology Department, Genetic Engineering and Biotechnology Research Division, National Research Centre, P.O. 12622, Giza, Egypt Full list of author information is available at the end of the article
}

Moringa tree has a wide range of medicinal and therapeutic properties, for example, anti-fibrotic, antiinflammatory, anti-microbial, anti-hyperglycemic, antioxidant, anti-tumor, and anti-cancer properties. Moringa leaves have a large amount of vitamin $C$, calcium, $\beta$ carotene, and potassium, and also, leaves are considered an essential source of different types of antioxidant compounds as flavonoids, ascorbic acid, carotenoids, and phenolics (Siddhuraju and Becker 2003). So, its leaves possess an antioxidant activity against free radicals and give significant protection against oxidative damage (Sreelatha and Padma 2009). 
Laser rays belong to unionizing radiation. The laser is an abbreviation of "light amplification by stimulation of radiation." Nowadays, the application of laser gained more attention in the field of agriculture (Pandey et al. 2015 and Swathy et al. 2016). Many studies have been reported the effect of laser on pre-sowing seeds in different crops and vegetables (Thatoi et al. 2016, Asghar et al. 2016, and Asghar et al. 2017). Laser radiation on seeds stimulates a series of positive effects such as enhancement of plant growth, reduction of germination time, increase in the number of flowers per plant, and increase of yield (Niculita et al. 2008).

Molecular markers are very useful in genetic analysis. The most commonly used marker systems are restriction fragment length polymorphisms (RFLPs), amplified fragment length polymorphisms (AFLPs), random amplified polymorphic DNAs (RAPDs), microsatellites or simple sequence repeats (SSRs), and inter-simple sequence repeats (ISSRs). The ISSR marker is used for amplification of the regions between microsatellite loci. This type of marker does not need any information about the amplified sequences and shows a large value of polymorphism in the samples. Similarly, ISSR is considered as an important marker in studies of genetic relationships (Joshi et al. 2000, Reddy et al. 2002, and Adawy et al. 2004).

Sodium dodecyl sulfate polyacrylamide gel electrophoresis (SDS-PAGE) is a biochemical technique used to analyze the effect of different treatments on genes expression. Protein profiling is important in studies related to abiotic and biotic stress (Kiegle et al. 2000 and Masoje et al. 2001). Previous studies showed that $\mathrm{He}-\mathrm{Ne}$ lasers influenced plant growth and metabolism, Govil et al. (1991) and Cai et al. (2000) investigated the enhancement of soluble protein content in the irradiated drying corn seedling. Similarly, the concentration of soluble proteins and the activities of functional proteins were increased significantly by the laser pretreatment (Chen et al. 2005).

Gao et al. (2016) reported that $\mathrm{He}-\mathrm{Ne}$ laser preillumination enhanced salt tolerance in tall fescue seedlings via upregulation expression level of some antioxidant enzyme genes and phytochrome $\mathrm{B}$ gene. They studied the effect of $\mathrm{He}-\mathrm{Ne}$ laser irradiation on cell wall reconstruction mediating by cell wall polysaccharides and DNA fragmentation in tall fescue seedlings and evaluated the role of cell wall reconstruction and DNA damage repair in the induction of enhanced adaption capacity to saline conditions by the laser irradiation and further explored the physicochemical mechanism of the protective effects of $\mathrm{He}-\mathrm{Ne}$ laser illumination on plants under unfavorable growth conditions.
This study aims to examine the comparative effect of $\mathrm{He}-\mathrm{Ne}$ laser irradiated seeds of moringa from Egypt on agro-morphological criteria, genomic DNA stability using ISSR markers and protein profiling using SDSPAGE.

\section{Materials and methods Plant materials}

Moringa oleifera L. seeds were collected from the farm of the Egyptian Scientific Society of Moringa, National Research Centre, Giza, Egypt.

\section{Laser parameters}

Experimental seeds were divided equally into two groups (dry and wetted). Twelve seeds were subjected to a helium-neon ( $\mathrm{He}-\mathrm{Ne}$ ) laser (model of the devise) with an average power density of $10 \mathrm{~mW} \mathrm{~cm}^{2}$ (wave length of $632.8 \mathrm{~nm}$ and beam diameter $=5 \mathrm{~cm}$ ) used to apply a dose of $300 \mathrm{~mJ} \mathrm{~cm}{ }^{2}$ for 25,45 , and $90 \mathrm{~min}$.

\section{Agro-morphological criteria}

The dry and wetted seeds irradiated with $\mathrm{He}-\mathrm{Ne}$ laser were planted in pots $(30 \times 25 \mathrm{~cm})$ under complete randomized design. Nine healthy seeds were sown in each pot at a depth of $\sim 2.5 \mathrm{~cm}$. The agro-morphological criteria (shoot length $(\mathrm{cm})$, shoot weight $(\mathrm{g})$, root length (cm), root weight $(\mathrm{g})$, number of leaves/plant and leaves weight/plant $(\mathrm{g})$ ) were recorded after 50 days from planting (seedling stage) to compare short-term laser effect with respect to the untreated control. The data of agromorphological criteria were statistically analyzed using the Co-State statistical program.

\section{Molecular analysis \\ ISSR-PCR}

The plant genomic DNA was isolated from the young leaves (15 days old seedling) using Gene Jet Plant Genomic DNA purification Mini Kits (Thermo Scientific K0791). The extracted genomic DNA was quantitated using a NanoDrop 1000 spectrophotometer (Thermo Scientific) and diluted to $50 \mathrm{ng} / \mu \mathrm{l}$ to use it as template for PCR.

ISSR-PCR was performed by using 12 ISSR primers (Table 1). PCR amplification for isolated DNA was performed in $0.2 \mathrm{ml}$ PCR Eppendorf $(25 \mu \mathrm{l})$ which consisted $12.5 \mu$ l Dream Taq green PCR Master Mix 2X (Thermo Scientific K1081), $1 \mu \mathrm{l}$ primer $(10 \mathrm{pmol})$ (Metabion, German), and $1 \mu \mathrm{l}$ Template DNA (50 ng/ $\mu \mathrm{l})$ and was completed to $25 \mu$ l by water (nuclease-free). Thermocycler (Bio-Rad) was programmed as follows: $94{ }^{\circ} \mathrm{C}$ for 5 min (one cycle) then $94{ }^{\circ} \mathrm{C}$ for $1 \mathrm{~min}, 45^{\circ} \mathrm{C}$ for $1 \mathrm{~min}$, $72{ }^{\circ} \mathrm{C}$ for $1.5 \mathrm{~min}$ (35 cycles), and finally, $72^{\circ} \mathrm{C}$ for $7 \mathrm{~min}$ (one cycle) and hold at $4{ }^{\circ} \mathrm{C}$. Then, $100 \mathrm{bp}$ DNA Ladder and $20 \mu \mathrm{l}$ of DNA amplified PCR product were loaded in 
Table 1 ISSR-PCR primers used for the genotyping of Moringa

\begin{tabular}{|c|c|c|}
\hline Name primer & Sequence $\left(5^{\prime}-3^{\prime}\right)$ & \\
\hline ISSR-6 & CGCGATAGATAGATAGATA & $\mathrm{CGC}(\mathrm{GATA})_{4}$ \\
\hline ISSR-7 & GACGATAGATAGATAGATA & $\mathrm{GAC}(\mathrm{GATA})_{4}$ \\
\hline ISSR-8 & AGACAGACAGACAGACGC & $(\mathrm{AGAC})_{4} \mathrm{GC}$ \\
\hline ISSR-9 & GATAGATAGATAGATAGC & $(\mathrm{GATA})_{4} \mathrm{GC}$ \\
\hline ISSR-10 & GACAGACAGACAGACAAT & $(\mathrm{GACA})_{4} \mathrm{AT}$ \\
\hline ISSR-11 & ACACACACACACACACYA & $(\mathrm{AC})_{8} \mathrm{YA}$ \\
\hline ISSR-12 & ACACACACACACACACYC & $(A C)_{8} Y C$ \\
\hline ISSR-13 & AGAGAGAGAGAGAGAGT & $(\mathrm{AG})_{8} \mathrm{~T}$ \\
\hline ISSR-16 & ТСТСТСТСТСТСТСТСТА & $(\mathrm{TC})_{8} \mathrm{TA}$ \\
\hline ISSR-HBO9 & GTGTGTGTGTGTGC & $(\mathrm{GT})_{6} \mathrm{GC}$ \\
\hline ISSR-HB-13 & GAGGAGGAGGC & $(\mathrm{GAG}) 3 \mathrm{GC}$ \\
\hline ISSR-HB14 & GTGGTGGTGGC & (GTG)3GC \\
\hline
\end{tabular}

$A$ adenine, $T$ thymine, $G$ guanine, $C$ cytosine each well of agarose (1.7\%), which was placed in $1 \mathrm{X}$ TAE buffer and ran at $100 \mathrm{~V}$ for about $2 \mathrm{~h}$. The gel was photographed by gel documentation (Bio-Rad) and was analyzed by Total Lab program to find out the molecular size of each band.

Genomic template stability (GTS \%) was calculated according to the equation described by Liu et al. (2007), GTS $=(1-a / n) \times 100$, where $a$ is the average number of polymorphic bands detected in each treated sample and $n$ is the number of total bands in the control .It was suggested that alternations in DNA profiles due to genotoxic exposure could be regarded as changes in genomic template stability (GTS, a qualitative measure of genotoxic effects).

\section{Protein profiling using SDS-PAGE}

SDS-PAGE was performed according to Laemmli (1970) and described by Tsugama et al. (2011). Soluble proteins were extracted by grinding $1 \mathrm{~g}$ leaves

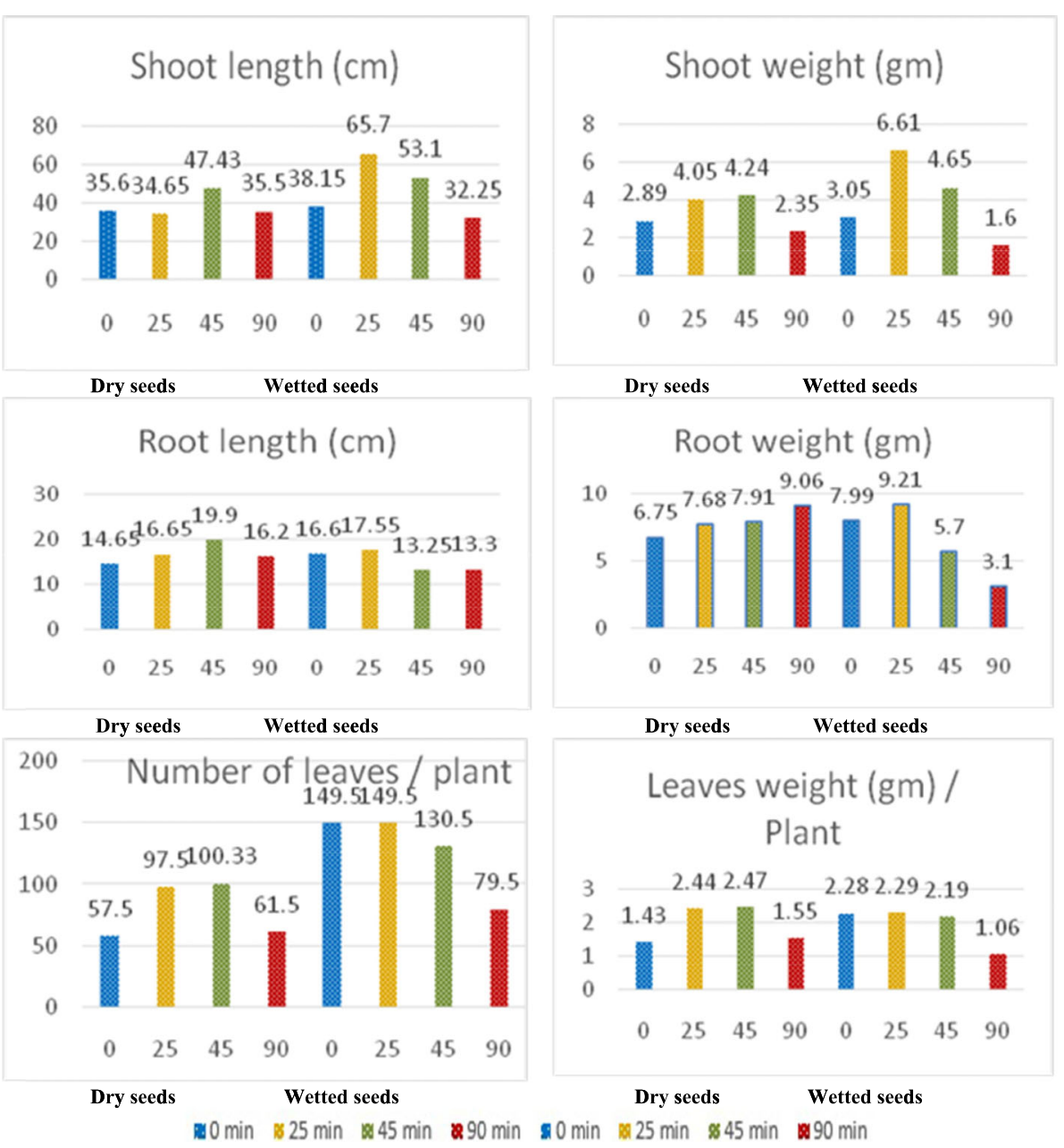

Fig. 1 Effect of He-Ne laser irradiation on agro-morphological criteria of moringa 
Table 2 Mean squares (MS) of analysis of moringa under the effect of He-Ne laser irradiation

\begin{tabular}{llllllll}
\hline Source & df & & & & & \\
\cline { 3 - 7 } & & & Shoon square (MS) & & & \\
\hline Replicates & 2 & $0.2722^{\text {ns }}$ & $0.5930^{\text {ns }}$ & $0.55^{\text {ns }}$ & $0.313^{\text {ns }}$ & $0.0935^{\text {ns }}$ & $0.9276^{\text {ns }}$ \\
Times & 7 & $0.000^{* * *}$ & $0.000^{* * *}$ & $0.000^{* * *}$ & $0.000^{* * *}$ & $0.000^{* * *}$ & $0.000^{* * *}$ \\
Error & 14 & 0.0166 & 0.237 & 1.323 & 0.048 & 0.0766 & 0.0387 \\
\hline
\end{tabular}

$d f$ degrees of freedom, $n s$ non-significant

***Highly significant at 0.005 level of probability

from each treatment, added to $1 \mathrm{ml}$ extraction buffer (10\% SDS, Glycerol, $1 \mathrm{M}$ Tris base, pH 8.8, $0.25 \mathrm{M}$ EDTA) in Eppendorf tube $(1.5 \mathrm{ml})$, left in the refrigerator overnight, then vortexed for $15 \mathrm{~s}$ and centrifuged at $12,000 \mathrm{rpm}$ at $4{ }^{\circ} \mathrm{C}$ for $20 \mathrm{~min}$. The supernatants which contain soluble proteins were transferred to new Eppendorf tubes and kept at deep-freeze until use for electrophoretic analysis, and the protein was then run in acrylamide gel $10 \%$ concentration. The marker of used protein is BLUltra Prestained Protein Ladder (GeneDirex, Cat No. PM001-0500). Protein bands were visualized by staining the gel using $0.1 \%$ Coomassie brilliant blue (R-250), and after the bands become clear, the gels were photographed by a digital camera (Sony, made in Japan) and transferred directly to the computer, and then the protein bands were analyzed by Total Lab program to find out the molecular mass of each band and scored depending on the presence $(+)$ and absence $(-)$ of bands.

\section{Results}

Effect of laser irradiation on agro-morphological criteria: The effect of $\mathrm{He}-\mathrm{Ne}$ laser on agro-morphological criteria such as root and shoot (lengths and weights) and leaves (number and weight) for dry and wetted seeds at different exposure times $(0,25,45$, and 90 min) were depicted in Fig. 1 and Tables 2 and 3. The seedling from wetted seeds that were irradiated for 25 and $45 \mathrm{~min}$ showed higher shoot length of 65.7 and $53.1 \mathrm{~cm}$ respectively, followed by dry seed irradiated for $45 \mathrm{~min}$ which had a shoot length of $47.43 \mathrm{~cm}$. The root length also was recorded to be higher in seedlings that were raised from laser-treated dry seeds for $45 \mathrm{~min}(19.9 \mathrm{~cm})$, followed by wetted seeds for $25 \mathrm{~min}$ $(17.55 \mathrm{~cm})$. The highest shoot fresh weight was recorded to be $6.61 \mathrm{~g}$ and $4.65 \mathrm{~g}$ in seedlings from wetted seeds that were irradiated for 25 and $45 \mathrm{~min}$, respectively. Similarly, the higher root fresh weight value was recorded to be $9.21 \mathrm{~g}$ in seedlings from wetted seeds that were irradiated for $25 \mathrm{~min}$ and 9.06 $\mathrm{g}$ in seedlings from dry seeds that were irradiated for $90 \mathrm{~min}$. The highest number of leaves were recorded 149.5 in seedlings from wetted seeds that were irradiated for 0 (control) and $25 \mathrm{~min}$, then 130.5 in seedlings from wetted seeds that were irradiated for 45 $\mathrm{min}$, while the number of leaves were recorded to be 97.5 and 10.33 in seedlings from dry seeds that were irradiated for 25 and $45 \mathrm{~min}$, respectively. The highest leaf weights were recorded to be $2.44 \mathrm{~g}$ and $2.47 \mathrm{~g}$ in seedlings from dry seeds that were irradiated for 25 and $45 \mathrm{~min}$, respectively. The leaf weights were recorded to be $2.28,2.29$, and $2.19 \mathrm{~g}$ in seedlings from wetted seeds that were irradiated for 0,25 , and 45 min, respectively.

\section{Effect of laser irradiation on moringa genome using ISSR marker}

Twelve primers were able to form amplified bands from control and treated seeds. A total of 172 amplified loci

Table 3 Mean performance values of moringa under the effect of He-Ne laser irradiation

\begin{tabular}{llllllllllllll}
\hline Seeds & Time (min) & Shoot length & \pm SD & Root length & \pm SD & No. of leaves & \pm SD & Shoot weight & \pm SD & Root weight & \pm SD & Leaves weight & \pm SD \\
\hline Dry & 0 & $35.60^{\mathrm{e}}$ & 0.2 & $14.65^{\mathrm{d}}$ & 1.15 & $57.50^{\mathrm{g}}$ & 0.5 & $2.89^{\mathrm{d}}$ & 0.03 & $6.75^{\mathrm{c}}$ & 0.17 & $1.43^{\mathrm{b}}$ & 0.09 \\
& 25 & $34.65^{\mathrm{f}}$ & 0.15 & $16.65^{\mathrm{c}}$ & 0.35 & $97.50^{\mathrm{d}}$ & 0.5 & $4.05^{\mathrm{c}}$ & 0.39 & $7.68^{\mathrm{b}}$ & 0.21 & $2.44^{\mathrm{a}}$ & 0.36 \\
& 45 & $47.43^{\mathrm{c}}$ & 0.05 & $19.90^{\mathrm{a}}$ & 0.00 & $100.33^{\mathrm{c}}$ & 1.53 & $4.24^{\mathrm{c}}$ & 0.05 & $7.91^{\mathrm{b}}$ & 0.72 & $2.47^{\mathrm{a}}$ & 0.11 \\
& 90 & $35.50^{\mathrm{e}}$ & 0.11 & $16.20^{\mathrm{c}}$ & 0.00 & $61.50^{\mathrm{f}}$ & 0.5 & $2.35^{\mathrm{e}}$ & 0.22 & $9.06^{\mathrm{a}}$ & 0.12 & $1.55^{\mathrm{b}}$ & 0.25 \\
Wetted & 0 & $38.15^{\mathrm{d}}$ & 0.15 & $16.60^{\mathrm{c}}$ & 0.40 & $149.50^{\mathrm{a}}$ & 0.5 & $3.05^{\mathrm{d}}$ & 0.19 & $7.99^{\mathrm{b}}$ & 0.04 & $2.28^{\mathrm{a}}$ & 0.04 \\
& 25 & $65.70^{\mathrm{a}}$ & 0.00 & $17.55^{\mathrm{b}}$ & 0.35 & $149.50^{\mathrm{a}}$ & 1.50 & $6.61^{\mathrm{a}}$ & 0.35 & $9.21^{\mathrm{a}}$ & 0.06 & $2.29^{\mathrm{a}}$ & 0.02 \\
& 45 & $53.10^{\mathrm{b}}$ & 0.2 & $13.25^{\mathrm{e}}$ & 0.15 & $130.50^{\mathrm{b}}$ & 1.53 & $4.65^{\mathrm{b}}$ & 0.19 & $5.70^{\mathrm{d}}$ & 0.15 & $2.19^{\mathrm{a}}$ & 0.22 \\
& 90 & $32.25^{\mathrm{g}}$ & 0.05 & $13.30^{\mathrm{e}}$ & 0.20 & $79.50^{\mathrm{e}}$ & 1.50 & $1.60^{\mathrm{f}}$ & 0.01 & $3.10^{\mathrm{e}}$ & 0.35 & $1.06^{\mathrm{c}}$ & 0.13 \\
\hline
\end{tabular}

For all value in each column with the same letter, the difference between the means is not statistically significant 


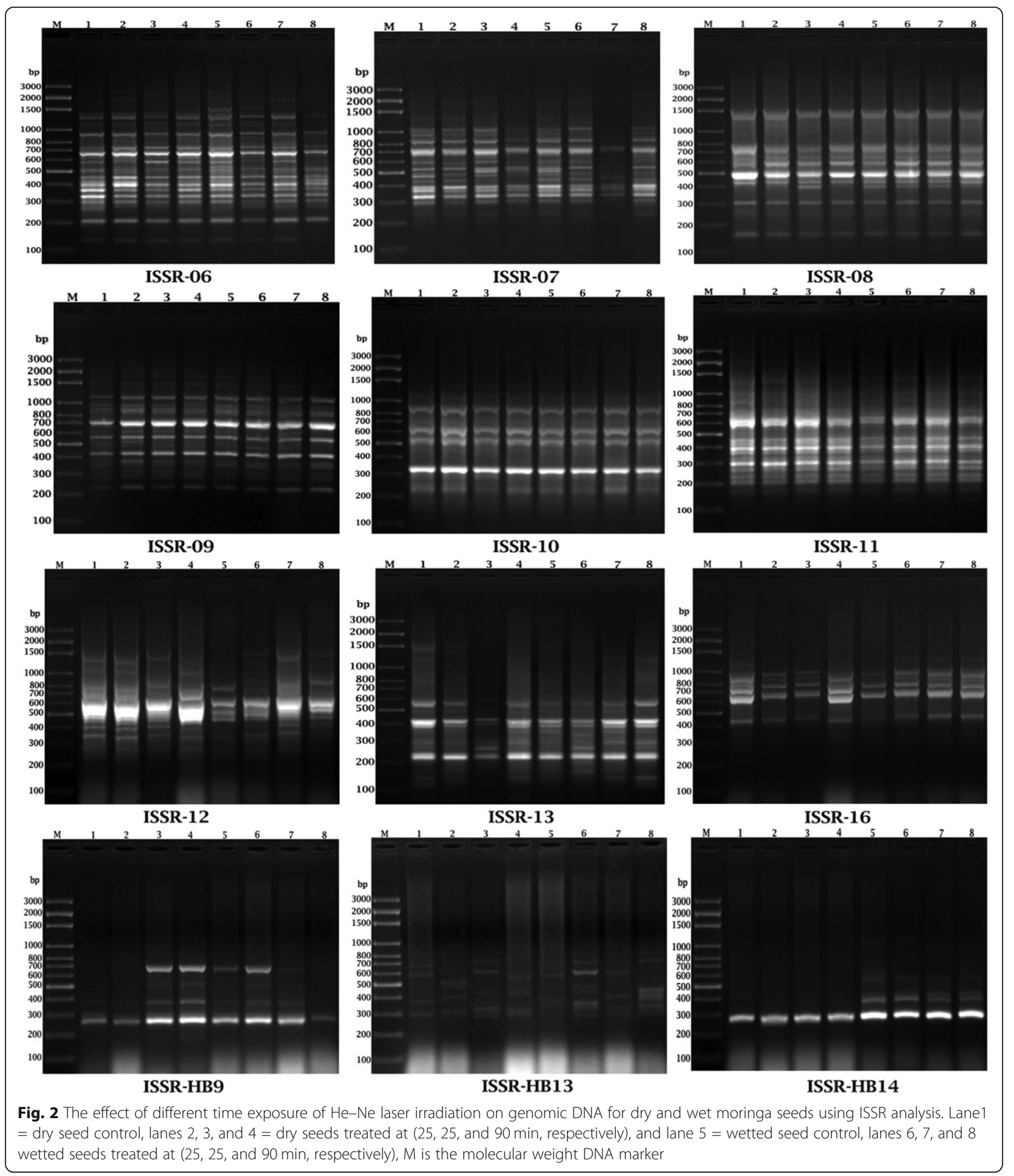

(bands) from the twelve primers were identified in the samples with molecular size ranging from 148 to 1618 bp (Fig. 2 and Tables 4 and 5). A total of 172 amplified bands produced 91 polymorphic bands with 19 unique bands mostly from wetted seeds (10 bands). The average of polymorphism in the studied samples was $52.91 \%$ (Table 4).

The maximum ISSR polymorphic bands compared to control were recorded 40 and 39 at exposure time $25 \mathrm{~min}$ in wetted seeds and 45 min of dry seeds, respectively (Table 5). 
Table 4 The effect of different time exposure of He-Ne laser irradiation on genomic DNA of dry and wetted moringa seeds using ISSR analysis

\begin{tabular}{|c|c|c|c|c|c|c|c|}
\hline Ser. no. & Primer & $\begin{array}{l}\text { Allele size } \\
\text { range (bp) }\end{array}$ & $\begin{array}{l}\text { Total number of } \\
\text { bands }\end{array}$ & $\begin{array}{l}\text { Monomorphic } \\
\text { bands }\end{array}$ & $\begin{array}{l}\text { Polymorphic } \\
\text { bands }\end{array}$ & Unique bands & $\begin{array}{l}\text { Polymorphism } \\
\text { percentage }\end{array}$ \\
\hline 1 & ISSR-6 & $148-1579 \mathrm{bp}$ & 24 & 14 & 10 & $\begin{array}{l}(232 \mathrm{bp}) \text { at } 90 \mathrm{~min} \text { (dry) } \\
(546 \mathrm{bp}) \text { at } 0 \text { min (wetted) }\end{array}$ & 41.6 \\
\hline 2 & ISSR-7 & $202-1413$ bp & 21 & 12 & 9 & $\begin{array}{l}(673 \mathrm{bp}) \text { at } 90 \mathrm{~min} \text { (wetted) } \\
(446 \mathrm{bp}) \text { at } 45 \mathrm{~min} \text { (wetted) } \\
(204 \mathrm{bp}) \text { at } 0 \text { min (dry) }\end{array}$ & 42.9 \\
\hline 3 & ISSR-8 & $168-1441 \mathrm{bp}$ & 12 & 11 & 1 & 0 & 8.33 \\
\hline 4 & ISSR-9 & $206-1609$ bp & 17 & 13 & 4 & 0 & 23.5 \\
\hline 5 & ISSR-10 & $225-1078 \mathrm{bp}$ & 10 & 9 & 1 & (251 bp) at 45 min (wetted) & 10 \\
\hline 6 & ISSR-11 & $188-1264$ bp & 13 & 10 & 3 & (867 bp) at 0 min (dry) & 23.1 \\
\hline 7 & ISSR-12 & 254-1491 bp & 17 & 3 & 14 & 0 & 82.4 \\
\hline 8 & ISSR-13 & $152-1471 \mathrm{bp}$ & 21 & 5 & 16 & $\begin{array}{l}(1333 \mathrm{bp}) \text { at } 25 \mathrm{~min} \text { (dry) } \\
(916 \mathrm{bp}) \text { at } 0 \text { min (dry) } \\
(573 \mathrm{bp}) \text { at } 45 \mathrm{~min}(\mathrm{dry}) \\
(310,164 \mathrm{bp}) \text { at } 25 \text { min (wetted) } \\
(285 \mathrm{bp}) \text { at } 45 \mathrm{~min} \text { (wetted) }\end{array}$ & 76.2 \\
\hline 9 & ISSR-16 & 438-1618 bp & 11 & 1 & 10 & (1681 bp) at 25 min (wetted) & 90.91 \\
\hline 10 & ISSR-HB9 & $201-674$ bp & 7 & 1 & 6 & (201 bp) at $90 \mathrm{~min}(\mathrm{dry})$ & 85.7 \\
\hline 11 & ISSR-HB13 & $288-871$ bp & 12 & - & 12 & $(524,418 \mathrm{bp})$ at $25 \mathrm{~min}$ (dry) & 100 \\
\hline 12 & ISSR-HB14 & $305-1189 \mathrm{bp}$ & 7 & 2 & 5 & $\begin{array}{l}\text { (1189 bp) at } 25 \mathrm{~min} \text { (wetted) } \\
\text { (1092 bp) at } 0 \text { min (wetted) }\end{array}$ & 71.4 \\
\hline \multicolumn{2}{|c|}{ Total number of bands } & - & 172 & 81 & 91 & 19 & 52.91 \\
\hline \multicolumn{2}{|l|}{ Average } & - & 14.33 & 6.75 & 7.58 & 1.6 & - \\
\hline
\end{tabular}

The percentage of genomic template stability (GTS \%) values were calculated in Table 5 . It recorded a maximum value $83.72 \%$ at $25 \mathrm{~min}$ (dry seeds) followed by $79.65 \%$ at $45 \mathrm{~min}$ (wetted seeds) and $90 \mathrm{~min}$ (dry and wetted seeds) and $77.32 \%$ at $45 \mathrm{~min}$ (dry seeds), while the minimum value was recorded $76.74 \%$ at 25 min (wetted seeds).

\section{Effect of laser irradiation on protein profile (SDS-PAGE)}

The application of laser irradiation $(\mathrm{He}-\mathrm{Ne})$ for 25,45 , and 90 min caused a significant effect on the expression of some genes that lead to changes in protein banding patterns of moringa as shown in (Fig. 3 and Table 6). The total number of 32 protein bands was recorded. The main polypeptide bands were located between 27 and 185 kilodaltons (KDa). Most changes were represented in the appearance of a few new bands with molecular weight $(\mathrm{Mw})$ of 155 and $76 \mathrm{KDa}$ in both dry and wetted seeds from all treatments and disappearance of some bands with Mw 120, 59, and $57 \mathrm{KDa}$ from some treatments of dry and wetted seeds (Table 6).

Also, from Fig. 3 and Table 6, it was concluded that at 25 min and 90 min treatments, the maximum number of protein bands were recorded 31 bands at 25 and $90 \mathrm{~min}$ in dry and wetted seeds, respectively. While the minimum number of protein bands were recorded 29 bands at $90 \mathrm{~min}, 45 \mathrm{~min}$ (dry seeds), and $25 \mathrm{~min}$ (wetted seeds) treatments. The percentage of polymorphic bands ( polymorphism) was recorded $15.6 \%$ in both dry and wetted seeds.

\section{Discussion}

Effect of laser irradiation on agro-morphological criteria The present investigation revealed that $\mathrm{He}-\mathrm{Ne}$ laser treatments on dry and wetted seeds at different exposure times $(0,25,45$, and $90 \mathrm{~min})$ had a significant effect on root and shoot (lengths and weights) and leaves (number and weight) as shown in Fig. 1 and Tables 2 and 3 . It was observed from agromorphological criteria values that laser exposure enhances the values of agro-morphological criteria of wetted seeds compared with dry seeds. The recommended exposure time of $\mathrm{He}-\mathrm{Ne}$ laser was recorded 25 min in wetted seeds while in dry seeds, it was recorded $45 \mathrm{~min}$; these exposure times gave the best agro-morphological values in most agro-morphological criteria.

Recently, it was observed that the physical methods had a biostimulatory role in a majority of agricultural crop plants. He-Ne laser was considered the most significant biophysical methods for enhancing the plant seed germination, different growth parameters, and plant development (rendering them safe and 
Table 5 Number of new appeared (+) and disappeared (-) bands as compared to control and genomic template stability (GTS) percentage of moringa seedlings pre-treated with laser light He-Ne using twelve ISSR primers

\begin{tabular}{|c|c|c|c|c|c|c|c|c|}
\hline \multirow[t]{2}{*}{ Primer } & & \multicolumn{3}{|l|}{ Dry seeds } & \multicolumn{3}{|l|}{ Wetted seeds } & \multirow[t]{2}{*}{ Cont } \\
\hline & & $25 \mathrm{~min}$ & $45 \mathrm{~min}$ & $90 \mathrm{~min}$ & $25 \mathrm{~min}$ & $45 \mathrm{~min}$ & $90 \min$ & \\
\hline \multirow[t]{2}{*}{ ISSR-6 } & + & 491 & 1107,266 & $1579,266,232$ & 1107,266 & 657 & 657 & 24 \\
\hline & - & 0 & 657,257 & 257 & $\begin{array}{l}546,491,417 \\
257\end{array}$ & $1579,546,417$ & $\begin{array}{l}1579,600 \\
546,491\end{array}$ & \\
\hline \multirow[t]{2}{*}{ ISSR-7 } & + & 0 & 509,202 & 0 & 0 & 446 & 673 & 21 \\
\hline & - & 204 & 204 & $\begin{array}{l}1413,473,431 \\
204\end{array}$ & 509 & $\begin{array}{l}1413,998,473 \\
431,509,202\end{array}$ & 509,202 & \\
\hline \multirow[t]{2}{*}{ ISSR-8 } & + & 0 & 398 & 0 & 0 & 0 & 0 & 12 \\
\hline & - & 0 & 0 & 0 & 0 & 0 & 398 & \\
\hline \multirow[t]{2}{*}{ ISSR-9 } & + & 366 & 366 & 366 & 463 & 507,463 & 366 & 17 \\
\hline & - & 463 & 0 & 507 & 612 & 0 & 612 & \\
\hline \multirow[t]{2}{*}{ ISSR-10 } & + & 0 & 0 & 0 & 0 & 251 & 0 & 10 \\
\hline & - & 0 & 0 & 0 & 0 & 0 & 0 & \\
\hline \multirow[t]{2}{*}{ ISSR-11 } & + & 0 & 0 & 0 & 1264,428 & 0 & 0 & 13 \\
\hline & - & 867,428 & 1264,867 & 1264,867 & 0 & 0 & 0 & \\
\hline \multirow[t]{2}{*}{ ISSR-12 } & + & 390,323 & 1341,744 & 323 & $\begin{array}{l}1491,1251,744 \\
390,354\end{array}$ & $\begin{array}{l}1341,744,684 \\
496,402,345,254\end{array}$ & $\begin{array}{l}1491,684 \\
402\end{array}$ & 17 \\
\hline & - & 402,345 & $1251,1972,684$ & $\begin{array}{l}1251,818,402 \\
345,307\end{array}$ & 818 & 0 & 307 & \\
\hline \multirow[t]{2}{*}{ ISSR-13 } & + & 1333, 177 & 573,251 & 329,177 & $251,310,164$ & $1158,285,152$ & $\begin{array}{l}1185,801 \\
251,152\end{array}$ & 21 \\
\hline & - & $1158,916,801$ & $\begin{array}{l}1435,1158,916 \\
827,801,471,152\end{array}$ & $\begin{array}{l}1435,916,827 \\
471\end{array}$ & 329,177 & 280 & 177 & \\
\hline \multirow[t]{2}{*}{ ISSR-16 } & + & 987,675 & 987,675 & 0 & $\begin{array}{l}1618,1270,900 \\
479,438\end{array}$ & $1270,900,479,438$ & $\begin{array}{l}1270,900 \\
479,438\end{array}$ & 11 \\
\hline & - & $1270,703,607$ & 703,607 & 1270,807 & 0 & 0 & 0 & \\
\hline \multirow[t]{2}{*}{ ISSR-HB9 } & + & 0 & $674,653,504$ & $\begin{array}{l}674,653,504 \\
201\end{array}$ & 504 & 0 & 0 & 7 \\
\hline & - & 380 & 0 & 0 & 0 & 653 & $\begin{array}{l}674,653 \\
380,300\end{array}$ & \\
\hline \multirow[t]{2}{*}{ ISSR-HB13 } & + & $524,476,418$ & $632,440,349,288$ & 440,321 & $\begin{array}{l}733,632,476 \\
440,349,321 \\
288\end{array}$ & 632,288 & $\begin{array}{l}871,733 \\
476,321\end{array}$ & 12 \\
\hline & - & $871,733,595$ & 871,595 & 871,733 & 595,398 & 595 & 595 & \\
\hline \multirow[t]{2}{*}{ ISSR-HB14 } & + & 0 & 0 & 0 & 1189,423 & 423 & 423 & 7 \\
\hline & - & 423 & 423 & 423 & 1092 & 1092 & 1092 & \\
\hline \multicolumn{2}{|c|}{ Total number of bands } & 28 & 39 & 35 & 40 & 35 & 35 & 172 \\
\hline \multicolumn{2}{|l|}{ GTS\% } & $83.72 \%$ & $77.32 \%$ & $79.65 \%$ & $76.74 \%$ & $79.65 \%$ & $79.65 \%$ & $100 \%$ \\
\hline
\end{tabular}

$(+)$ appearance of new bands, (-) disappearance of normal bands

friendly to the environment) (Asghar et al. 2017). Similar results were investigated by Urva et al. (2017), who stated that seedling growth parameters for 10day-old seedlings were enhanced under the effect of 25,50 , and $75 \mathrm{~mJ}$ low-power continuous-wave laser light in Moringa oleifera, and optimum laser energy level has more acceleratory effect since at three laser energy levels, the responses were significant.
$\mathrm{He}-\mathrm{Ne}$ laser irradiation caused a significant effect on seed germination, growth parameters, enzyme activity, and thermodynamic properties of the Triticum aestivum plant (Jamil et al. 2013). Similarly, continuous laser $\mathrm{He}-\mathrm{Ne}$ wave with low power had an effect on the thermodynamics of seed, the rate of germination, and the activity of enzymes during germination process in sunflower (Perveen et al. 2010). 


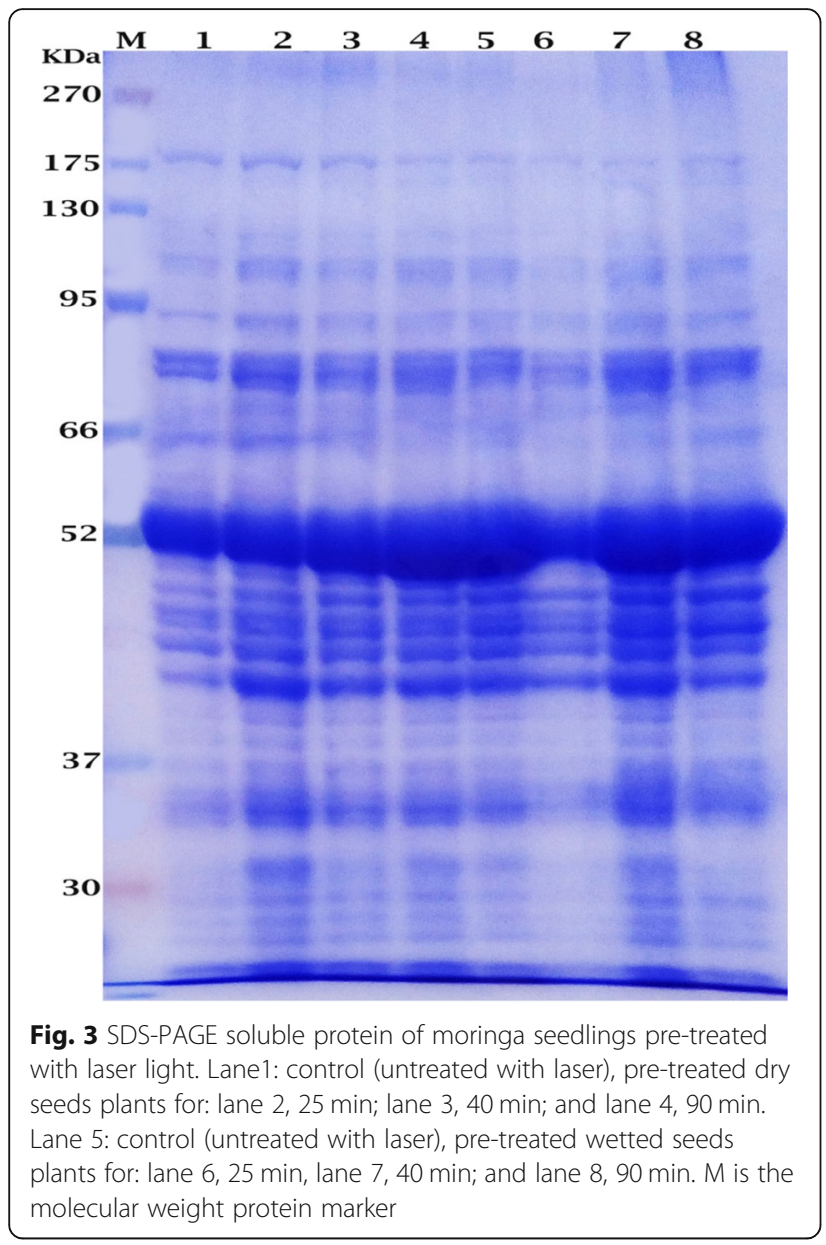

\section{Effect of laser irradiation on moringa genome using ISSR marker}

ISSR profiles evaluated remarkable differences between the control and $\mathrm{He}-\mathrm{Ne}$ laser-treated seedlings (dry and wetted) with different primers (Fig. 2 and Tables 4 and 5). Twelve primers were used to compare the control with dried and wetted moringa seeds treated with $\mathrm{He}-$ $\mathrm{Ne}$ laser at different times. Atienzar and Jha (2006) and Ozturk et al. (2010) stated that the difference in DNA profile reflected the nucleotide substitution or alterations (point mutations) to complex chromosomal rearrangements. The results indicated disappearance $(-)$ of normal bands and appearance of new bands $(+)$ in comparison with the control. A total of 172 amplified bands produced 91 polymorphic bands, and 19 bands of them were unique bands mostly from wetted seeds (10 bands) with $52.91 \%$ polymorphic average.

The disappearance of bands may be referred to the presence of DNA photoproducts (e.g., pyrimidine dimers), which can reduce amplification of DNA in the PCR reaction (Donahue et al. 1994 and Atienzar et al. 2000). The disappearance of the amplified bands mainly affected the high molecular weight bands because the odds of obtaining DNA photoproducts increase with the length of the amplified fragment (Atienzar et al. 2000). On the other hand, mutations (new annealing events) can only be responsible for the appearance of new bands if they occur at the same locus. A minimum of $10 \%$ of mutations may be required to get a new PCR product (Atienzar et al. 2000). Thus, the new loci could be referred to mutations while DNA damage leads to the disappearance of loci (bands).

GTS \% is related to the level of DNA damage, the efficiency of DNA repair, and replication. DNA polymorphism detected by the ISSR technique in different treatments as compared with the control could be used as an investigation tool for further sequencing studies and as a beneficial technique. Changes in the ISSR profile induced by laser treatments can be regarded as changes in genomic DNA template stability, and these genetics effects can be directly compared with alteration in other parameters.

It was found that the minimum value of GTS \% was $76.74 \%$, and this value was recorded at laser exposure time $25 \mathrm{~min}$ on wetted seeds. There is an inverse relationship between GTS \% and polymorphism value; this means that the wetted seeds' exposure to laser radiation for $25 \mathrm{~min}$ recorded minimum GTS \% and maximum polymorphism values. This may be related to the improvement some of agro-morphological criteria such as shoot length and weight, root weight, and number of leaves.

GTS \% indicated changes in ISSR profiles to compare their changes with different growth parameters (root and shoot length) in moringa plants. DNA analysis considered a more sensitive test, since it is able to detect temporary DNA changes that may not finally appear as mutations (Labra et al. 2003).

\section{Effect of laser irradiation on proteins profile (SDS-PAGE)}

The alterations in the electrophoretic patterns of leaf proteins are indicative of the ability of both dry and wetted seed treatments to alter the gene expression of plant. Protein profile changes were represented in the appearance of few new bands with molecular weight $(\mathrm{Mw}) 155$ and $76 \mathrm{KDa}$ in both dry and wetted seeds at all treatments and disappearance of some bands such that having Mw 120, 59, and $57 \mathrm{KDa}$ for some treatments of dry and wetted seeds (Fig. 3 and Table 6). Some electrophoretic bands disappeared due to the deletion of their corresponding genes (El-Khallal and Mohamed 2004). On the other hand, the appearance of new characteristic bands could be explained on the basis of the mutational event at the regulatory system of the unexpected gene(s) that activate it (Abdelsalam et al. 1993 and 1997 and El-Nahas 
Table 6 SDS-PAGE of soluble proteins of two weeks old of moringa seedlings pre-treated with laser light

\begin{tabular}{|c|c|c|c|c|c|c|c|c|c|c|c|}
\hline \multirow{2}{*}{$\begin{array}{l}\text { Number of } \\
\text { bands }\end{array}$} & \multirow{2}{*}{$\begin{array}{l}\mathrm{MW} \\
(\mathrm{KDa})\end{array}$} & \multicolumn{5}{|c|}{ Dry seeds } & \multicolumn{5}{|c|}{ Wetted seeds } \\
\hline & & Control & $25 \mathrm{~min}$ & $45 \mathrm{~min}$ & $90 \mathrm{~min}$ & Polymorphism & Control & $25 \min$ & $45 \min$ & $90 \mathrm{~min}$ & Polymorphism \\
\hline 1 & 185 & + & + & + & + & M & + & + & + & + & M \\
\hline 2 & 155 & - & + & + & + & P & - & + & + & + & P \\
\hline 3 & 120 & + & - & - & - & $P$ & + & - & - & - & P \\
\hline 4 & 115 & + & + & + & + & M & + & + & + & + & M \\
\hline 5 & 112 & + & + & + & + & M & + & + & + & + & M \\
\hline 6 & 106 & + & + & + & + & M & + & + & + & + & M \\
\hline 7 & 102 & + & + & + & + & M & + & + & + & + & M \\
\hline 8 & 93 & + & + & + & + & M & + & + & + & + & M \\
\hline 9 & 82 & ++ & ++ & ++ & ++ & M & ++ & ++ & ++ & + & M \\
\hline 10 & 79 & ++ & ++ & ++ & ++ & $M$ & ++ & ++ & ++ & + & $M$ \\
\hline 11 & 76 & - & + & + & + & $P$ & - & + & + & + & $P$ \\
\hline 12 & 70 & + & + & + & + & $M$ & + & + & + & + & $M$ \\
\hline 13 & 65 & + & + & + & + & $M$ & + & + & + & + & $M$ \\
\hline 14 & 59 & + & + & - & - & $P$ & + & - & - & + & P \\
\hline 15 & 57 & + & + & - & - & $P$ & + & - & + & + & $P$ \\
\hline 16 & 52 & +++ & +++ & +++ & +++ & $M$ & +++ & +++ & +++ & +++ & $M$ \\
\hline 17 & 49 & + & + & + & + & $M$ & + & + & + & + & $M$ \\
\hline 18 & 47 & ++ & ++ & ++ & ++ & $M$ & ++ & ++ & ++ & ++ & $M$ \\
\hline 19 & 45 & + & + & + & + & $M$ & + & + & + & + & $M$ \\
\hline 20 & 44 & ++ & ++ & ++ & ++ & $M$ & ++ & ++ & ++ & ++ & $M$ \\
\hline 21 & 43 & ++ & ++ & ++ & ++ & $M$ & ++ & ++ & ++ & ++ & $M$ \\
\hline 22 & 41 & ++ & ++ & ++ & ++ & $M$ & ++ & ++ & ++ & ++ & $M$ \\
\hline 23 & 39 & + & + & + & + & $M$ & + & + & + & + & $M$ \\
\hline 24 & 38 & + & + & + & + & $M$ & + & + & + & + & $M$ \\
\hline 25 & 37 & + & + & + & + & $M$ & + & + & + & + & $M$ \\
\hline 26 & 36 & + & + & + & + & $M$ & + & + & + & + & $M$ \\
\hline 27 & 35 & ++ & ++ & ++ & ++ & $M$ & ++ & ++ & ++ & ++ & $M$ \\
\hline 28 & 34 & ++ & ++ & ++ & ++ & $M$ & ++ & ++ & ++ & ++ & $M$ \\
\hline 29 & 31 & ++ & ++ & ++ & ++ & $M$ & ++ & ++ & ++ & ++ & $M$ \\
\hline 30 & 29 & + & + & + & + & $M$ & + & + & + & + & $M$ \\
\hline 31 & 28 & + & + & + & + & $M$ & + & + & + & + & $M$ \\
\hline 32 & 27 & + & + & + & + & $M$ & + & + & + & + & $M$ \\
\hline \multicolumn{2}{|c|}{$\begin{array}{l}\text { Total number of } \\
\text { bands }\end{array}$} & 30 & 31 & 29 & 29 & $\%$ of poly-morphism = 15.6 & 30 & 29 & 30 & 31 & $\%$ of poly-morphism = 15.6 \\
\hline \multicolumn{2}{|c|}{$\begin{array}{l}\text { Mean of } \\
\text { polymorphism }\end{array}$} & 15.6 & & & & & & & & & \\
\hline
\end{tabular}

$P$ polymorphic bands, $M$ monomorphic bands

2000). Also, Telma et al. (2008) documented that the treatment with a short term of oxidative stress lead to overexpression of different genes encoding heat shock proteins. Changes in the band intensity may be resulted by certain mutational events that would have occurred in the regulatory genes, which would lead to inhibition, attenuation, or constitutive gene expression. Therefore, the corresponding bands become faint or become more intense. This conclusion is in accordance with Abdelsalam et al. (1993) and Gamal El-Din et al. (1988), as they stated that increased band intensity is due to duplication of chromosomal complement in treated plants. These variations included appearance of new bands, disappearance of some bands, and changes in band intensity in comparison with control plants. The same results were 
reported by the other authors (Fayez 2000 and Telma et al. 2008).

\section{Conclusions}

It was conducted from the present research that $\mathrm{He}-$ Ne laser treatment of wetted seeds achieves biostimulation in many aspects of agro-morphological criteria. In general, most agro-morphological criteria increased especially with wetted seed group pre-laser treatments ( $25 \mathrm{~min}$ ) in comparison with the dry seed groups. ISSR analysis is a highly sensitive method for the detection of DNA alteration induced by laser treatments. The exposure of dry and wetted seeds to $\mathrm{He}-$ $\mathrm{Ne}$ laser at different times affects the genomic template stability percentage (GTS \%); GTS \% considers a highly sensitive parameter compared with the traditional methods such as root and shoot lengths. Also, the laser treatments have a great effect on gene expression by switch on or off for some genes that lead to presence or absence of certain proteins, respectively. Finally, the SDS-PAGE, ISSR analysis, and other growth parameters are considered an important tool for identifying DNA profile change induced by laser treatments.

\section{Abbreviations \\ A: Adenine; AFLPs: Amplified fragment length polymorphisms; C: Cytosine; df: Degrees of freedom; DNA: Deoxy ribonucleic acid; \\ EDTA: Ethylenediaminetetraacetic acid; G: Guanine; GTS\%: Genomic template stability percentage; He-Ne: Helium-neon; ISSRs: Inter-simple sequence repeats; LSD: Least significant difference at 0.05; M: Monomorphic band; MS: Mean square; ns: Non-significant; P: Polymorphic band; RAPDs: Random amplified polymorphic DNAs; RFLPs: Restriction fragment length polymorphisms; SD: Standard deviation; SDS-PAGE: Sodium dodecyl sulfate polyacrylamide gel electrophoresis; SSRs: Simple sequence repeats (microsatellites); T: Thymine}

\section{Acknowledgements}

The authors are grateful to all the researchers whom we cited in this review for their significant and valuable research.

\section{Authors' contributions}

SAO and WAR preformed the laboratory analysis. SAO and WAR wrote the paper, performed the data, and coordinated the data collection. So, this work was carried out in collaboration between the two authors. Both authors read and approved the final manuscript.

\section{Funding}

There are currently no funding sources in the design of the study and collection, analysis, and interpretation of data and in writing the manuscript.

\section{Availability of data and materials \\ Not applicable}

\section{Ethics approval and consent to participate}

Not applicable

\section{Consent for publication}

Not applicable

\section{Competing interests}

The authors declare that they have no competing interests.

\section{Author details}

${ }^{1}$ Genetics and Cytology Department, Genetic Engineering and Biotechnology Research Division, National Research Centre, P.O. 12622, Giza, Egypt. ${ }^{2}$ Botany Department, Faculty of Science, Ain Shams University, Cairo, Egypt.

Received: 14 July 2019 Accepted: 15 October 2019

Published online: 07 January 2020

\section{References}

Abdelsalam AZ, Hassan HZ, Badawy FMI, Abdel-Naby WM (1993) The mutagenic potentialities of three pesticides on three biological system. Egypt J Genet Cytol 22:109-128

Abdelsalam AZ, Hassan HZ, Soliman A, Bahieldin A (1997) Differential mutagenic activities of two aromatic compounds due to different side chain as revealed by cytological analysis and biochemical genetic indices. Egypt J Genet Cytol 26:121-142

Adawy SS, Hussein EHA, El-Khishin D, Saker MM, Mohamed AA, El-Itriby HA (2004) Genotyping Egyptian date palm cultivars using RAPD, ISSR, AFLP markers and estimation of genetic stability among tissue culture derived plants. Arab J Biotech 8(1):99-114

Asghar T, Iqbal M, Jamil Y, Zia ul H, Nisar J, Shahid M (2017) Comparison of HeNe LASER and sinusoidal non-uniform magnetic field seed pre-sowing treatment effect on Glycine max (Var 90-I) germination, growth and yield, J Photochem Photobiol B Biol 166: 212-219.

Asghar T, Jamil Y, lqbal M, Zia ul H, Abbas M (2016) Laser light and magnetic field stimulation effect on biochemical, enzymes activities and chlorophyll contents in soybean seeds and seedlings during early growth stages. J Photochem Photobiol B Biol 165: 283-290.

Atienzar FA, Cordi B, Donkin MB, Evenden AJ, Jha AN, Depledge MH (2000) Comparison of ultraviolet-induced genotoxicity detected by random amplified polymorphic DNA with chlorophyll fluorescence and growth in a marine macroalgae, Palmaria palmate. Aquatic Toxicol 50:1-12

Atienzar FA, Jha AN (2006) The random amplified polymorphic DNA (RAPD) assay and related techniques applied to genotoxicity and carcinogenesis studies: a critical review. Mutation Res 613:76-102

Cai SW, Qi Z, Ma XL (2000) The effect of He-Ne laser irradiation on soluble protein synthesis of corn seedling. Chin J Lasers 27:284-288

Chen YP, Yue M, Wang XL (2005) Influence of He-Ne laser irradiation on seeds thermodynamic parameters and seedlings growth of Isatis indogotica. Plant Sci 168:601-606

Donahue BA, Yin S, Taylor JS, Reines D, Hanawalt PC (1994) Transcript cleavage by RNA polymerase II arrested by a cyclobutane pyrimidine dimer in the DNA template. Proc Natl Acad Sci USA 91:8502-8506

El-Khallal SM, Mohamed THR (2004) Changes in growth protein pattern, DNA finger prints and chromosomal aberrations of water stressed maize seedlings treated with abscisic or jasmonic acid. Egypt J Biotechnol 18:32-338

El-Nahas Al (2000) Mutagentic potential of imazethapyr herbicide (pursuit) on Vicia faba. In the presence of urea fertilizers. Pak J Biol Sci 3:900-905

Fayez KA (2000) Action of photosynthetic diuron herbicide on cell organelles and biochemical constituents of the leaves of two soybean cultivars. Pest Biochem Physiol 66:105-115

Gamal El-Din AY, Hussein EHA, Eweda MA (1988) Variations in chromosome number and its bearing on electrophortic protein banding pattern in Vicia. Bull Fac Agric Cairo Univ 39(1):143-153

Gao L, Li Y, Han R (2016) Cell wall reconstruction and DNA damage repair play a key role in the improved salt tolerance effects of He-Ne laser irradiation in tall fescue seedlings. Biosci Biotechnol Biochem 80(4):682-693

Gopalakrishnan L, Doriya K, Kumar DS (2016) Moringa oleifera: a review on nutritive importance and its medicinal application. Food Sci Hum Wellness 5(2):49-56

Govil SR, Agrawal DC, Rail KP, Thakur SN (1991) Physiological responses of Vigna radita $\mathrm{L}$. to nitrogen and argon laser irradiation, Indian J. Plant Physiol $1: 72-76$

Jamil Y, Perveen R, Ashraf M, Ali Q, Igbal M, Ahmad MR (2013) He-Ne laserinduced changes in germination, thermodynamic parameters, internal energy and enzyme activities of wheat during germination and early growth physiological attributes. Laser Phys Lett 10:045606-045614

Joshi SP, Gupta YS, Aggarwal RK, Ranjekar PK, Brar DS (2000) Genetic diversity and phylogenetic relationship as revealed by inter-simple sequence repeat (ISSR) polymorphism in the genus Oryza. Theor Appl Genet 100:1311-1320 
Kiegle E, Moore CA, Haseloff J, Tester MA, Knight MR (2000) Cell-type specific calcium responses to drought, salt and cold in the Arabidopsis root. Plant J 23:267-278

Labra M, Fabio TD, Grassi F, Regondi SMG (2003) AFLP analysis as biomarker of exposure to organic and inorganic genotoxic substances in plants. Chemosphere 52:1183-1188

Laemmli UK (1970) Cleavage of structural proteins during assembly of head bacteriophage T4. Nature 227: 680-8-685.

Leone A, Fiorillo G, Criscuoli F, Ravasenghi S, Santagostini L, Fico G, Pozzi F (2015) Nutritional characterization and phenolic profiling of Moringa oleifera leaves grown in Chad, Sahrawi refugee camps, and Haiti. Int J Mol Sci 16(8): 18923-18937

Liu W, Yang YS, Zhou QX, Xie LJ, Li PJ, Sun T (2007) Impact assessment of cadmium contamination on rice (Oryza sativa L.) seedling at molecular and population levels using multiple biomarkers. Chemosphere 67:1155-1163

Masoje PB, Myskow B, Milczarski P (2001) Extending a RFLP-based genetic map of rey using random amplified polymorphic DNA (RAPD) and isozyme markers. Theor Appl Genet 102:1273-1279

Niculita P, Danaila-Guidea SM, Livadariu O, Esofina R, Mona P, Ristici M, Patroi A, Negoita M (2008) Testing the effect induced by the simultaneous treatment with magnetic field and laser light field, modulated at audio frequencies, on colonies of Alternaria alternate. Rom Biotechnol Lett 13(2):3643-1650

Ozturk F, Duman F, Leblebici Z, Temizgul R (2010) Arsenic accumulation and biological responses of watercress (Nasturtium officinale R. Br.) exposed to arsenite. Environ Exp Bot 69: 167-174.

Pandey JK, Dubey G, Gopal R (2015) Study the effect of insecticide dimethoate on photosynthetic pigments and photosynthetic activity of pigeon pea: laser-induced chlorophyll fluorescence spectroscopy. J Photochem Photobiol B Biol 151:297-305

Perveen R, Ali Q, Ashraf M, Al-Qurainy F, Jamil Y, Ahmad MR (2010) Effects of different doses of low power continuous wave He-Ne laser radiation on some seed thermodynamic and germination parameters, and potential enzymes involved in seed germination of sunflower (Helianthus annuus L.). Photochem Photobiol 86:1050-1055

Reddy PM, Sarla N, Siddiq EA (2002) Inter simple sequence repeat (ISSR) polymophism and its application in plant breeding. Euphytica 128:9-7

Siddhuraju P, Becker K (2003) Antioxidant properties of various solvent extracts of total phenolic constituents from three different agroclimatic origins of drumstick tree (Moringa oleifera Lam.) leaves. J Agri Food Chem 51: $2144-2145$

Sreelatha S, Padma PR (2009) Antioxidant activity and total phenolic content of Moringa oleifera leaves in two stages of maturity. Plant Foods Hum Nutr 64:303-311

Swathy SP, Kiran KR, Rao MS, Mahato KK, Rao MR, Satyamoorthy K, Muthusamy A (2016) Responses of He-Ne laser irradiation on agronomical characters and chlorogenic acid content of brinjal (Solanum melongena L.) var. Mattu Gulla. J Photochem Photobiol B Biol 164:182-190

Telma ES, Zanor ML, Valle EM (2008) Investigating the role of plant heat shock proteins during oxidative stress. Plant Signal Behav 3(10):856-857

Thatoi P, Kerry RG, Gouda S, Das G, Pramanik K, Thatoi H, Patra JK (2016) Photomediated green synthesis of silver and zinc oxide nanoparticles using aqueous extracts of two mangrove plant species, Heritiera fomes and Sonneratia apetala and investigation of their biomedical applications. J Photochem Photobiol B Biol 163:311-318

Tsugama D, Liu S, Takano T (2011) A rapid chemical method for lysing Arabidopsis cells for protein analysis. Plant Methods 7:22. https://doi.org/10 1186/1746-4811-7-22

Urva SH, Jamilb Y, Haqa Z, Mujahida T, Khanc AU, Iqbald M, Abbase M (2017) Low power continuous wave-laser seed irradiation effect on Moringa oleifera germination, seedling growth and biochemical attributes. J Photochem Photobiol B Biol 170:314-323

\section{Publisher's Note}

Springer Nature remains neutral with regard to jurisdictional claims in published maps and institutional affiliations.

\section{Submit your manuscript to a SpringerOpen ${ }^{\circ}$ journal and benefit from:}

- Convenient online submission

- Rigorous peer review

- Open access: articles freely available online

- High visibility within the field

- Retaining the copyright to your article

Submit your next manuscript at $\boldsymbol{\nabla}$ springeropen.com 